\title{
RECOVERY AND GERMINABILITY OF NATIVE SEED FED TO CATTLE
}

\author{
Marina K. Whitacre ${ }^{1,2}$ and Christopher A. Call1,3
}

\begin{abstract}
AвstRact.-Using livestock as seed dispersal agents may be an effective method for increasing species diversity on degraded and previously seeded rangelands. We quantified seed passage and recovery rates, and post-passage germinability of Wyoming big sagebrush (Artemisia tridentata Nutt. ssp. wyomingensis Beetle \& Young), bottlebrush squirreltail (Elymus elymoides [Raf.] Swezey), and gooseberry globemallow (Sphaeralcea grossulariaefolia [H. \& A.] Rydb.) by feeding Holstein heifers seeds of each species at 3 levels $(15,000 ; 30,000$; and 60,000 seeds) over a period of 3 weeks. One-kg fecal samples were collected 1, 2, 3, and 4 days after seed ingestion. Undamaged seeds were extracted from the samples and tested for germinability. Globemallow had the highest percentage of recovered, undamaged seed, followed by squirreltail and sagebrush. Globemallow and sagebrush seed passage was highest on Day 1, after which seed numbers dropped sharply. Squirreltail passage and recovery were more consistent through time, with higher seed recovery at lower seed feeding levels. Post-passage germinability was highest for squirreltail and globemallow on Day 1 . Sagebrush germination was negligible. Differences in physical seed properties (size, shape, and seed coat) likely influenced interspecies variation in passage, recovery, and germinability. Globemallow and squirreltail seeds may be suited for livestock dispersal, but sagebrush seeds are not.
\end{abstract}

Key words: fecal seeding, seed dispersal, revegetation, bottlebrush squirreltail, Elymus elymoides, gooseberry globemallow, Sphaeralcea grossulariaefolia, Wyoming big sagebrush, Artemisia tridentata ssp. wyomingensis.

Livestock seed dispersal is gaining recognition as a method to reintroduce desirable species on degraded rangelands (Archer and Pyke 1991). Seeds fed to livestock pass through the gut and are deposited in a favorable environment for germination and establishment (Herrick et al. 1996). Due to the nature of dung pat deposition, seeds are distributed in patches across the landscape. If seeds germinate and become established plants, satellites of desirable species have the potential to increase in size and number through vegetative propagation or seed production (Archer and Pyke 1991). Since dung pats persist in arid climates (Bornemissza 1960), livestock seed dispersal may be well-suited to distribute and store long-lived seeds on the landscape until conditions are favorable for germination and establishment. Although slower than more traditional methods, livestock seed dispersal may be a long-term revegetation technique that can incrementally increase plant diversity across a landscape.

Seed properties of selected species, such as size, shape, density, and seed coat smoothness and hardness, are important determinants in the success of livestock seed dispersal as a revegetation tool (Simao Neto et al. 1987, Gardener et al. 1993). The selection of species with seed properties resistant to digestive processes (to retain high germinability) and properties that reduce retention time in the gut is restrictive but critical for success, and this demonstrates that livestock seed dispersal is not a viable seeding option for all plant species (Gardener et al. 1993).

Despite these complexities, livestock seed dispersal as an alternative seeding method continues to be of interest. Several seed feeding trials have quantified seed passage and postpassage germination for a number of plant species (Simao Neto et al. 1987, Al-Mashikhi 1993, Doucette et al. 2001, Gökbulak 2002), and others have quantified seedling emergence and survival in artificial and natural dung pats (Barrow and Havstad 1992, Gardener et al. 1993, Ocumpaugh et al. 1996, Shinderman and Call 2001, Gökbulak and Call 2004). Many studies have used seed properties to explain differences in rates of passage, recovery, and post-passage germinability; however, the results have been inconclusive.

\footnotetext{
${ }^{1}$ Department of Forest, Range and Wildlife Sciences, Utah State University, Logan, Utah 84322-5230.

${ }^{2}$ Present address: Escalante Ranger District, Dixie National Forest, U.S. Forest Service, Escalante, UT 84726

${ }^{3}$ Corresponding author.
} 
TABLE 1. Physical characteristics (mean $\pm s_{\bar{x}}$ ) of sagebrush, globemallow, and squirreltail seed fed to heifers.

\begin{tabular}{lrcccrrr}
\hline Species & $\begin{array}{c}50 \text {-seed } \\
\text { weight }(\mathrm{mg})\end{array}$ & $\begin{array}{c}\text { Length } \\
(\mathrm{mm})\end{array}$ & $\begin{array}{c}\text { Width } \\
(\mathrm{mm})\end{array}$ & $\begin{array}{c}\text { Specific } \\
\text { gravity }\end{array}$ & \multicolumn{2}{c}{ Volume of bulk seed fed $(\mathrm{mL})$} \\
\cline { 6 - 9 } & $8( \pm 0.2)$ & $1.3( \pm 0.0)$ & $0.6( \pm 0.0)$ & $>1$ & 113 & 225 & 450 \\
Sagebrush & $50( \pm 0.4)$ & $1.6( \pm 0.0)$ & $1.3( \pm 0.0)$ & $>1$ & 18 & 38 & 75 \\
Globemallow & $253( \pm 2.5)$ & $9.3( \pm 0.1)$ & $1.6( \pm 0.0)$ & $=1$ & 300 & 600 & 1200 \\
Squirreltail & & & & &
\end{tabular}

aNumber of seeds

The primary objective of this study was to determine seed passage, recovery, and postpassage germinability for 3 native species, globemallow (Sphaeralcea grossulariaefolia [H. \& A.] Rydb.), bottlebrush squirreltail (Elymus elymoides [Raf.] Swezey), and Wyoming big sagebrush (Artemisia tridentata Nutt. ssp. wyomingensis Beetle \& Young), which have not been previously tested in cattle. We were also interested in the influence of seed level intake and gut retention time on seed passage, recovery, and germinability, and how physical seed characteristics may explain the outcome.

\section{Materials AND Methods}

The 3 plant species selected for this study are cool-season, drought-tolerant perennials native to the Great Basin region of the western United States. They represent 3 life forms (grass, forb, and shrub) historically present at a companion field site in Skull Valley, Utah. Seeds were obtained from a commercial seed source (Granite Seed Company, Lehi, Utah) in July 2001 and stored at $20^{\circ} \mathrm{C}$ in plastic woven sacks for 1 month prior to the start of the study. Bottlebrush squirreltail is a short-lived perennial grass species with an elongated seed, and was chosen for this study because of its early seral characteristics (Hironaka 1994, Jones 1998). Although referred to as a "seed" in this article, the dispersal unit for bottlebrush squirreltail and other grasses is technically a floret, which is comprised of a caryopsis (1seeded fruit) enclosed by a lemma and palea (accessory bracts). Gooseberry globemallow, a broadleaf herbaceous species, was chosen for its ability to colonize disturbed areas (Wasser 1982). The seed is dense, kidney-shaped, and has a hard, smooth seed coat. Wyoming big sagebrush, an evergreen shrub that provides cover and winter forage for wildlife (Stubbendieck et al. 1992), was chosen because of its disappearance on Great Basin rangelands due to increased fire frequency (Whisenant 1990). Its seed is a very small, delicate achene.

Seed weight, size (length and width), and relative specific gravity were measured to describe physical seed characteristics for each species (Table 1). Ten 50-seed replicates of each species were weighed to obtain an average 50-seed weight. We measured 100 seed lengths and widths of each species with the aid of a dissecting scope. Relative specific gravity was determined by placing three 50seed replicates of each species in water that contained a drop of dishwashing detergent to reduce surface tension (Ortmann et al. 1998).

A seed-feeding study was conducted in August 2001 at the Utah State University Caine Dairy Teaching and Research Center to quantify seed passage rates and seed recovery. Nine Holstein heifers, similar in age $(21 \pm 4$ months old), weight (568 $\pm 79 \mathrm{~kg})$, and gestation (79 \pm 23 days pregnant) were kept in separate tie stalls for three 5-day trials. The heifers were fed a standard grass hay diet (Bromus inermis Leysser, Dactylis glomerata L., Festuca arundinacea Schreb., Phleum pratense L., Juncus spp.; $69 \%$ in vivo dry matter digestibility, $7.8 \%$ crude protein, $63.3 \%$ neutral detergent fiber, and $39.2 \%$ acid detergent fiber) ad libitum in the morning and evening and had continual access to water. For 2 mornings prior to the start of the study and every morning thereafter, $500 \mathrm{~mL}$ of calf feed (IFA Newborn Calf "D" $18 \%$ Starter with steamed flaked soybeans and Deccox ${ }^{\mathrm{R}}$ ) mixed with $30 \mathrm{~mL}$ liquid molasses was fed to the heifers to familiarize them with the medium used to facilitate seed feeding. Between trials, the heifers were released for 2 days and allowed to move freely.

Three heifers were randomly assigned to each species and fed 15,000;30,000; or 60,000 seeds, with a different seed feeding level for each of the 3 trials. During each trial, every seed intake level was represented for all species. On the 1st morning of each trial, the assigned 
seed amount was added to the calf feed / molasses mixture in a 2:1 ratio of calf feed to seed. Molasses was used to adhere the seed to the calf feed.

Total fecal output for each heifer was quantified by weighing fecal matter collected behind each animal every 12 hours. We collected 100-g samples from each heifer on the 2nd day of the 3 rd trial, placed them in a drying oven for 48 hours at $60^{\circ} \mathrm{C}$, and then reweighed them to quantify moisture content of the dung.

We collected 1-kg fecal samples from the rectum 1, 2, 3, and 4 days after the seed was ingested to test for daily variation in seed passage, recovery, and germinability. Samples were weighed on site and immediately washed through a series of sieves. The residual fiber and seed were transported to the lab and airdried. Samples containing squirreltail and globemallow seeds were run through an air column seed separator to remove the finer material. We examined remaining material using a 10X magnifying lens to separate seed from fiber. Sagebrush seed was too light for the seed separator; therefore, the dried samples were sorted by hand under a dissecting scope to recover and count the seed. Once extracted from the dung samples, the seeds were divided into 3 categories: damaged, undamaged, and germinated. A seed was categorized as germinated when the coleoptile emerged and the radicle elongated to at least $5 \mathrm{~mm}$ (Copeland 1978). To determine the effect of seed intake level and gut retention time on seed passage rate and recovery for each species, the cumulative seed count for each species, seed intake level, and collection time was multiplied by the total fecal output per day.

To test germinability following passage, 4 replicates of 25 undamaged seeds for each species at each seed intake level and collection time were placed on moistened filter paper in petri dishes in a germination chamber set at $10 / 20^{\circ} \mathrm{C}$ with a 12 -hour photoperiod. The control included 4 replicates of 25 unpassed, undamaged seeds of each species. The petri dishes were stacked 5-6 high and rotated daily within the stacks and within the chamber to account for any light or temperature variability. The seeds were monitored daily for 28 days. As seeds germinated (when the coleoptile emerged, and the radicle elongated to at least $5 \mathrm{~mm}$; Copeland 1978), they were removed and recorded. Since several treatments had fewer than 100 seeds $\cdot \mathrm{kg}^{-1}$ sample, germinability was reported as a percentage to provide a meaningful comparison between treatment combinations.

\section{Experimental design and analysis}

Percent recovery and germination of undamaged seed, and fecal output were analyzed using analysis of variance in the repeated measures mixed procedure of SAS when residuals could be normalized (SAS 2001). When normalization was not possible, as for sagebrush germination because of a high number of zeros, means and standard errors were calculated. The covariate structure was unstructured.

A split-split plot experimental design was used to test post-passage recovery and germinability of squirreltail, globemallow, and sagebrush seed. The whole plot experimental unit was heifer (1-9), and the whole plot factor was species (squirreltail, globemallow, and sagebrush). The subplot experimental unit was trial (1-3), and the subplot factor was seed intake level $(15,000 ; 30,000$; and 60,000 seeds per heifer). The sub-subplot unit was a repeated measure on trial, and the sub-subplot factor was time (seed collection day 1-4).

The initial percent recovery model included 3 explanatory variables: species, seed intake, and collection day. We were also interested in the effect of seed intake and collection day on each species and ran a 2nd recovery analysis by species with 2 explanatory variables: seed intake and collection day. In all recovery analyses, seed recovery percentages were cube root-transformed prior to running the analysis of variance.

The germination model for undamaged seed of each species had 1 explanatory variable: time. We used arcsine-transformed germination data for squirreltail analysis and raw germination data for globemallow analysis. Sagebrush germination residuals could not be normalized due to a high number of zeros. The fecal output model included 4 explanatory variables: trial, species, seed intake, and collection day.

\section{Results \\ Fecal Output}

Mean fecal output per heifer per day was $14.9 \mathrm{~kg}\left(s_{\bar{x}}=0.41\right)$. The species of seed eaten and seed intake level were not significant in 
TABLE 2. Mean $\left( \pm s_{\bar{x}}\right)$ recovery (\% of seed ingested) of sagebrush, globemallow, and squirreltail seed collected from dung $1,2,3$, and 4 days after seed ingestion $(n=9)$. Seed recovery means followed by a different letter are significantly different $(P \leq 0.05)$ within species.

\begin{tabular}{lcccrr}
\hline & \multicolumn{4}{c}{ Recovery by day $(\%)$} & \multicolumn{2}{c}{$\begin{array}{c}\text { Total } \\
\text { Species }\end{array}$} & 1 & 2 & 3 & 4 & recovery $(\%)$ \\
\cline { 2 - 5 } & $7.3 \mathrm{a}( \pm 2.4)$ & $1.0 \mathrm{~b}( \pm 0.3)$ & $0.1 \mathrm{c}( \pm 0.0)$ & $0.0 \mathrm{~d}( \pm 0.0)$ & $8.4( \pm 1.9)$ \\
Sagebrush & $28.3 \mathrm{a}( \pm 10.5)$ & $16.5 \mathrm{~b}( \pm 3.9)$ & $5.0 \mathrm{c}( \pm 1.6)$ & $0.4 \mathrm{~d}( \pm 0.1)$ & $50.2( \pm 6.5)$ \\
Globemallow & $5.9 \mathrm{a}( \pm 1.0)$ & $7.4 \mathrm{a}( \pm 1.4)$ & $4.9 \mathrm{ab}( \pm 1.1)$ & $3.1 \mathrm{~b}( \pm 1.0)$ & $21.3( \pm 1.2)$ \\
Squirreltail & &
\end{tabular}

TABLE 3. Mean $\left( \pm s_{\bar{x}}\right)$ squirreltail seed recovery (\% of seed ingested) from dung 1, 2, 3, and 4 days after seed ingestion. Heifers $(n=3)$ were fed 3 quantities of seed $(15,000 ; 30,000 ; 60,000)$. Seed recovery means followed by a different letter are significantly different $(P \leq 0.05)$ within seed intake.

\begin{tabular}{lcrrrrrr}
\hline $\begin{array}{l}\text { Number of } \\
\text { seeds fed }\end{array}$ & 1 & 2 & 3 & & \multicolumn{2}{c}{$\begin{array}{c}\text { Total } \\
\text { recovery }(\%)\end{array}$} & $\begin{array}{c}\text { Total seeds } \\
\text { recovered }\end{array}$ \\
\cline { 2 - 6 } & $6.8 \mathrm{a}( \pm 1.3)$ & $8.3 \mathrm{a}( \pm 2.8)$ & $8.7 \mathrm{a}( \pm 1.5)$ & $6.0 \mathrm{a}( \pm 2.3)$ & $29.8( \pm 1.8)$ & 4470 \\
15,000 & $6.2 \mathrm{a}( \pm 3.1)$ & $10.0 \mathrm{a}( \pm 2.7)$ & $4.0 \mathrm{~b}( \pm 0.5)$ & $2.7 \mathrm{c}( \pm 0.6)$ & & $22.9( \pm 2.5)$ & 6870 \\
30,000 & $4.8 \mathrm{a}( \pm 0.5)$ & $4.3 \mathrm{a}( \pm 0.6)$ & $2.3 \mathrm{~b}( \pm 0.7)$ & $1.0 \mathrm{c}( \pm 0.1)$ & & $12.4( \pm 1.0)$ & 7440 \\
60,000 & & & & & & & \\
\hline
\end{tabular}

determining output $(P=0.4609$ and $P=$ 0.4849 , respectively). Variation in output was significantly affected by trial and day $(P<$ 0.0001 for both). Output gradually increased from Trial 1 to 3 and was highest on Days 2, 3, and 4 . The moisture content of the dung was $84.6 \%\left(s_{\bar{x}}=0.003\right)$.

\section{Seed Recovery}

The 3-way interaction between species, seed intake level, and collection day was significant for undamaged seed recovery (hereafter, seed recovery; $P=0.0054)$. When seed recovery was analyzed by species, we found that seed from all species (sagebrush, globemallow, and squirreltail) was affected by gut retention time $(P<0.0001, P<0.0001$, and $P=0.0022$, respectively; Table 2 ).

Seed intake level did not affect seed recovery of sagebrush and globemallow $(P=0.9472$ and $P=0.8131$, respectively); however, it did affect the recovery of squirreltail seeds $(P=$ $0.0003)$. When 15,000 squirreltail seeds were fed, percent recovery was consistent over time; however, at the higher seed intake levels, seed recovery declined between Days 2 and 3, and Days 3 and 4 (Table 3). A comparison of percent seed recovery by day across seed intake levels shows lower squirreltail recovery at the 60,000 seed intake level on Days 2, 3, and 4. Total recovery also dropped as the number of seeds fed increased (Table 3).
Total seed recovery was highest for globemallow, followed by squirreltail and sagebrush (Table 2). Seed recovery by day was highest on Day 1 for sagebrush and globemallow. Sagebrush seed recovery declined progressively from Day 1 to 3, and globemallow recovery continued to decline through Day 4. Squirreltail seed recovery was more consistent over time.

\section{Seed Germinability}

Gut retention time decreased the germinability of globemallow and squirreltail $(P=$ 0.0207 and $P>0.001$, respectively; Table 4$)$. The reduction in seed germinability due to increasing passage time was lowest for globemallow, followed by squirreltail. Germinability was highest for globemallow and squirreltail when gut retention time was minimized. Squirreltail germinability declined from Day 1 to 3, and leveled off by Day 4. Globemallow germinability declined from Day 1 to 2 but not from Day 2 to 3 . There was an insufficient number of globemallow seeds recovered on Day 4 to test for germination. Post-passage sagebrush germination was negligible (only 1 seed germinated; Table 4).

Recovered seeds classified as "germinated" during the recovery process were $2 \%-4 \%$ of the total recovered seed count for globemallow at all collection times, and 3\% for squirreltail on Day 1 . We found 4 germinated sagebrush 
TABLE 4. Mean $\left( \pm s_{\bar{x}}\right)$ germination of unpassed (Day 0) and passed globemallow, squirreltail and sagebrush seed. Passed seed was collected 1, 2, 3, and 4 days after heifers ingested seed $(n=12)$. Germination means followed by a different letter are significantly different $(P \leq 0.05)$ within species.

\begin{tabular}{lccccc}
\hline & \multicolumn{5}{c}{ Mean germination by day $(\%)$} \\
\cline { 2 - 6 } Species & 0 & 1 & 2 & 3 & 4 \\
\hline Sagebrush & $64 \mathrm{a}( \pm 7.5)$ & $0.002 \mathrm{~b}$ & $0.00 \mathrm{~b}$ & $\S$ & $\S$ \\
Globemallow & $40 \mathrm{a}( \pm 1.6)$ & $17.7 \mathrm{~b}( \pm 2.1)$ & $8.7 \mathrm{c}( \pm 1.9)$ & $10.4 \mathrm{c}( \pm 3.1)^{\mathrm{a}}$ & $\S$ \\
Squirreltail & $90 \mathrm{a}( \pm 3.8)$ & $29.3 \mathrm{~b}( \pm 2.8)$ & $13.3 \mathrm{c}( \pm 2.2)$ & $4.7 \mathrm{~d}( \pm 1.1)$ & $6.7 \mathrm{~d}( \pm 1.2)$ \\
\hline
\end{tabular}

$a_{n}=10$

$\S$ Too few seeds recovered to test germination

seeds $(0.11 \%)$ in the recovered seeds from Day 1.

\section{Discussion}

Increased gut retention time often correlates with lower recovery rates and post-passage germinability, as found with all 3 species tested in this study. Recovery dropped sharply for sagebrush after Day 1 and for globemallow after Day 2. Squirreltail recovery was also significantly affected by time but was more consistent. Similar reductions in seed recovery have been noted for several other native grass and forb species of western North America, including Poa secunda, Bouteloua curtipendula, Pseudoroegneria spicata, Pascopyrum smithii, Sporobolus airoides, Elymus cinereus, Hesperostipa comata, Sphaeralcea coccinea, Balsamorhiza sagittata, and Linum lewisii (Barrow and Havstad 1992, Al-Mashikhi 1993, Gökbulak 1998, 2002, Doucette et al. 2001, Shinderman and Call 2001). The germinability of globemallow, squirreltail, and sagebrush seed was reduced $56 \%, 67 \%$, and $100 \%$, respectively, after 1 day in the gut. Reductions in post-passage germinability have also been noted in other native grass and forb species of western North America, including Bouteloua curtipendula, Poa secunda, Pascopyrum smithii, Nassella viridula, Buchloe dactyloides, Panicum virgatum, Pseudoroegneria spicata, Elymus cinereus, Hesperostipa comata, Achnatherum hymenoides, Sporobolus airoides, Balsamorhiza sagittata, Sphaeralcea coccinea, Ratibida columnifera, and Linum lewisii (Barrow and Havstad 1992, Al-Mashikhi 1993, Ocumpaugh et al. 1996, Ortmann et al. 1998, Gökbulak 1998, 2002, Doucette et al. 2001, Shinderman and Call 2001).

The interaction between physical seed properties and morphology of the ruminant diges- tive tract may explain some of the interspecies variation in passage rate, recovery, and postpassage germinability. Small, round seeds with smooth exteriors, similar to those of globemallow, typically have faster passage rates, higher recovery, and improved germinability because the seeds more readily separate from the digesta than rough or elongated seeds (Gardener et al. 1993). Seeds $<2.5 \mathrm{~mm}$ in diameter also have unrestricted passage through the reticuloomasal orifice in cattle (Poppi et al. 1980), while larger seeds have longer resident times in the rumen, resulting in repeated rumination and mastication. In this study, the elongated shape of squirreltail seed may have made it more susceptible to mastication and less able to pass through the reticulo-omasal orifice (Russi et al. 1992). In addition, the length of squirreltail seed is approximately the size of ingesta particles that trigger rumination $(10 \mathrm{~mm}$; Welch and Hooper 1988). These factors may have contributed to the negative effect seed intake level had on squirreltail recovery.

Seed density can also interact with the ruminant digestive tract to influence recoverability and germinability of ingested seed. Ingested materials are stratified into 3 primary zones of the rumen based on specific gravity. Lighter solids are flushed back into the rumen, and smaller, denser materials are passed through the reticulo-omasal orifice (Van Soest 1994). These seed-digestive tract interactions may explain the quick passage of relatively dense globemallow and sagebrush seeds, and the more consistent passage of less dense squirreltail seeds.

Seed coat hardness can increase the likelihood of seed survival by protecting the seed from mastication and digestion (Archer and Pyke 1991). Seeds with high hard content, such as legumes, are protected from digestive processes and are successfully disseminated in 
dung (Gardener et al. 1993). In contrast, softcoated seeds can imbibe water, exposing the embryo to a caustic environment within the digestive tract (Mohamed-Yasseen et al. 1994). In our study, very few sagebrush seeds were recovered (approximately $0.6 \%$ of the total ingested), and only 1 germinated in the germination experiment. Its soft seed coat (N. Shaw, 2001, personal communication) may have overridden its beneficial size and density. For squirreltail seeds (florets), the lemma and palea likely provided some protection to the enclosed caryopsis; however, it appears that these accessory bracts may be more susceptible to time spent in the gut than the seed coat of globemallow, as indicated by a $>50 \%$ drop in germination between Days 1 and 2, and Days 2 and 3 . Also, germinated squirreltail seeds were only recovered from the dung samples collected on Day 1, suggesting that imbibed seeds after Day 1 were digested.

The physical properties of globemallow seed (dense, with a smooth, hard seed coat) are those favored for high passage rates (Gardener et al. 1993), and they likely played a role in the seed's high passage rate within 2 days of ingestion. Half of the seed ingested was recovered, more than twice the recovery of squirreltail and 6 times the recovery of sagebrush. Globemallow also had the most consistent post-passage germination $(8.7 \%-17.7 \%)$. A hydrophobic substance in the seed coat of globemallow may have also aided globemallow recovery and germination by preventing some of the seed from imbibing and prematurely exposing the embryo and cotyledons (Page et al. 1966).

Differences in recovery cannot be explained solely by the interactions between physical seed properties and digestive tract morphology. Poa secunda seeds are half the size of squirreltail and Pseudoroegneria spicata seeds; therefore, based on size, $P$. secunda should have the highest recovery (Gökbulak 1998), and P. spicata and squirreltail should have similar recoveries. Instead, recoveries of $P$. spicata and $P$. secunda on Day 1 in Gökbulak's study (1998), regardless of amount fed, were 5-6 times that of squirreltail in our study. This suggests that there are factors (sex, age, fecal output), other than the physical seed characteristics discussed here, that affect passage and recovery rates.

An additional factor that may influence seed recovery is seed intake level, which has not been widely explored. Prior to this study, only
6 species (4 grasses and 2 legumes) have been fed in different amounts to test effect on seed recovery. One study used sheep (Jones and Simao Neto 1987) and another used steers (Gökbulak 1998). Although we cannot directly compare results because age, size, sex, and species of ruminant can influence digestion (Simao Neto et al. 1987, Lyford 1988), there are some commonalities. For instance, the level of sagebrush and globemallow seed intake did not affect percent seed recovery in Holstein heifers as found in sheep with 4 pasture species, 2 of which are similar in size and weight to globemallow and sagebrush (Trifolium semipilosum cv. Safari, a legume, and Axonopus affinis, a grass; Jones and Simao Neto 1987). Similarly, Gökbulak (1998) found the level of seed intake did not influence $P$. spicata recovery in Holstein steers. In contrast, squirreltail seed recovery declined as seed intake increased, as Gökbulak (1998) found with P. secunda seed. The decline in squirreltail seed recovery as seed intake increased may be a result of the increased volume of slow passing seed (Table 1), which could lead to increased retention time and reduced recovery. Based on Jones and Simao Neto (1987), Gökbulak (1998), and our study, seed passage is less commonly affected by seed intake level, and the mechanisms that create the effect are not clear.

It is unlikely that seeds of squirreltail, globemallow, and sagebrush are naturally dispersed by large herbivores such as cattle. Long awns facilitate wind dispersal of squirreltail seeds and deter consumption by large herbivores (Marlette and Anderson 1986). Globemallow seeds are primarily dispersed by ants, and to a lesser extent by small mammals and birds (Mull 2003). Sagebrush seeds are typically dispersed short distances by wind, although there is some dispersal via water and small mammals (Walton et al. 1986). Yet, seed production and seed bank reserves for many native species may be limited or nonexistent in large, cheatgrass-dominated stands that experience frequent fires (Whisenant 1990). And, the dispersal of propagules from native communities into adjacent crested wheatgrass stands can be very limited (Marlette and Anderson 1986). In these situations, cattle that have been fed commercially available seed of native species may facilitate seed dispersal as they graze cheatgrass and crested wheatgrass stands. 
Our results indicate that globemallow and squirreltail may be amenable to fecal seeding. It should be emphasized, however, that fecal seeding in a managerial setting introduces additional factors that can strongly influence seedling emergence and survival. For example, previous studies have found that dung pat thickness and surface crusting, seed location within the dung pat, timing of precipitation, and resident vegetation influence seedling emergence and survival (Akbar 1994, Auman et al. 1998, Gökbulak and Call 2004). Limited establishment of squirreltail or globemallow was documented in a companion field study in Skull Valley, Utah (Whitacre 2004). Failure was attributed to drought and high densities of Mormon crickets (Anabrus simplex). However, globemallow seedling establishment occurred in dung for 4 consecutive spring seasons following dung deposition, demonstrating that in dry years, dung pats may provide a protected cache of seeds until conditions are favorable for germination. More studies on livestock seed dispersal are needed in realistic, managerial settings to verify whether fecal seeding may be a viable technique for increasing plant species diversity on degraded and previously seeded rangelands.

\section{ACKNOWLEDGMENTS}

This study was funded by the Utah Agricultural Experiment Station, Utah State University, Logan, Utah, and approved as Journal Paper 7628.

\section{Literature Cited}

AквAR, G. 1994. Dungpat microenvironmental effects on germination and establishment of crested wheatgrass. Doctoral dissertation, Utah State University, Logan.

AL-Mashikhi, M.S. 1993. Influence of the ruminant digestive process on the germinability of range forage species. Master's thesis, Utah State University, Logan.

Archer S., AND D.A. Pyke. 1991. Plant-animal interactions affecting plant establishment and persistence on revegetated rangelands. Journal of Range Management 44:558-565.

Auman, B.S., C.A. Call, and R.D. Wiedmeier. 1998. Crested wheatgrass establishment in livestock dung deposited on degraded rangeland vegetation types in the Intermountain West, USA. Arid Soil Research and Rehabilitation 12:317-333.

Barrow, J.R., and K.M. Havstad. 1992. Recovery and germination of gelatin-encapsulated seeds fed to cattle. Journal of Arid Environments 22:395-399.

Bornemissza, G.F. 1960. Could dung eating insects improve our pastures? Journal of the Australian Institute of Agricultural Science 26:54-56.
Copeland, L.O. 1978. Rules for testing seed. Proceedings of the Association of Seed Analysts. Journal of Seed Technology 3:1-126.

DoucetTe, K.M., K.M. Wittenburg, And W.P. McCaughey. 2001. Seed recovery and germination of reseeded species fed to cattle. Journal of Range Management 54:575-581.

Gardener, C.J., J.G. McIvor, and A. Jansen. 1993. Passage of legume and grass seeds through the digestive tract of cattle and their survival in faeces. Journal of Applied Ecology 30:63-74.

GÖKBULAK, F. 1998. Seed dispersal by livestock: a revegetation application for improving degraded rangelands. Doctoral dissertation, Utah State University, Logan.

2002. Effect of American bison (Bison bison L.) on the recovery and germinability of seeds of range forage species. Grass and Forage Science 57:395-400.

GÖKBULAK, F., AND C.A. CALL. 2004. Grass seedling recruitment in cattle dungpats. Journal of Range Management 56:649-655.

Herrick, J.E., K.M. Havstad, and D.P. Coffin. 1996. Rethinking remediation technologies for desertified landscapes. Journal of Soil and Water Conservation 52:220-225.

HironaKa, M. 1994. Medusahead: natural successor to the cheatgrass type in the northern Great Basin. Pages 89-91 in S.B. Monsen and S.G. Kitchen, compilers, Proceedings - ecology and management of annual rangelands. General Technical Report INT-GTR-313. USDA Forest Service, Intermountain Research Station, Ogden, UT.

Jones, R.M., And M. Simao Neto. 1987. Recovery of pasture seed ingested by ruminants. 3 . The effects of the amount of seed in the diet and the diet quality on seed recovery from sheep. Australian Journal of Experimental Agriculture 27:253-256.

JonES, T.A. 1998. Viewpoint: the present status and future prospects of squirreltail research. Journal of Range Management 51:326-331.

LYFORD, S.L. 1988. Growth and development of the ruminant digestive system. Pages 44-63 in D.C. Church, editor, The ruminant animal: digestive physiology and nutrition. Prentice-Hall, Englewood Cliffs, NJ. $564 \mathrm{pp}$.

Marlette, G.M., And J.E. Anderson. 1986. Seed banks and propagule dispersal in crested wheatgrass stands. Journal of Applied Ecology 23:161-175.

Mohamed-Yasseen, Y., S.A. Barringer, W.E. SplittStoesser, and S. Costanza. 1994. The role of seed coats in seed viability. Botanical Review 60:426-439.

MuLL, J.F. 2003. Dispersal of sagebrush-steppe seeds by the western harvester ant (Pogonomyrmex occidentalis). Western North American Naturalist 63:358-362.

Ocumpaugh, W.R., S. Archer, and J.W. Stuth. 1996. Switchgrass recruitment from broadcast seed vs. seed feed to cattle. Journal of Range Management 49:368-371.

Ortmann, J., W.H. Schacht, J. Stubbendieck, and D. Brink. 1998. The "foliage is the fruit" hypothesis: complex adaptations in buffalograss (Buchloe dactyloides). American Midland Naturalist 140:252-263.

Page, R.J., D.L. Goodwin, And N.E. West. 1966. Germination requirements of scarlet globemallow. Journal of Range Management 19:145-146.

Poppi, D.P., B.W. Norton, D.J. Minson, And R.E. HendERICKSEN. 1980. The validity of the critical size theory 
for particles leaving the rumen. Agricultural Science 94:275-280.

Russi, L., P.S. Cocks, and E.H. Roberts. 1992. The fate of legume seeds eaten by sheep from a Mediterranean grassland. Journal of Applied Ecology 29: $772-778$.

SAS Institute, INC. 2001. SAS/STAT user's guide, version 8.2. SAS Institute, Inc., Cary, NC.

Shinderman, M.J., AND C.A. CaLl. 2001. Establishment of forbs in cattle dungpats deposited in vegetation gaps in a degraded sagebrush community. Ecological Restoration 19:99-106.

Simao Neto, M., R.M. Jones, and D. Ratcliff. 1987. Recovery of pasture seed ingested by ruminants. 1 . Seed of six tropical pasture species fed to cattle, sheep and goats. Australian Journal of Experimental Agriculture 27:239-246.

Stubbendieck, J., S.L. Hatch, and C.H. Butterfield, 1992. North American range plants. 4th edition. University of Nebraska Press, Lincoln. 493 pp.

VAN SoEsT, P.J. 1994. Nutritional ecology of the ruminant. 2nd edition. Comstock Publishing Associates, Cornell University Press, Ithaca, NY. 476 pp.

Walton, T.P., R.S. White, and C.L. Wambolt. 1986. Artemisia reproductive strategies: a review with emphasis on plains silver sagebrush. Pages 67-74 in E.D. McArthur and B.L. Welch, compilers, Proceedings-symposium on the biology of Artemisia and
Chrysothamnus. General Technical Report INT-200. USDA Forest Service, Intermountain Research Station, Ogden, UT.

WASsER, C. 1982. Ecology and culture of selected species useful in revegetating disturbed lands in the West. FWS/OBS-82/56. USDI Fish and Wildlife Service, Washington, DC. 347 pp.

Welch J.G., AND A.P. HoOper. 1988. Ingestion of feed and water. Pages 108-116 in D.C. Church, editor, The ruminant animal: digestive physiology and nutrition. Prentice-Hall, Englewood Cliffs, NJ. 564 pp.

Whisenant, S.G. 1990. Changing fire frequencies on Idaho's Snake River Plains: ecological and management implications. Pages 4-10 in E.D. McArthur, E.M. Romey, S.D. Smith, and P.T. Tueller, compliers, Proceedings-symposium on cheatgrass invasion, shrub die-off, and other aspects of shrub biology and management. General Technical Report INT-GTR276. USDA Forest Service, Intermountain Research Station, Ogden, UT.

WhitaCre, M.K. 2004. Cattle as grazing management and seed dispersal tools for increasing native species diversity on Great Basin rangelands. Master's thesis, Utah State University, Logan, UT.

Received 18 October 2004

Accepted 4 May 2005 